\title{
QUALITY ASSURANCE AND ITS MANAGEMENT FOR ENGINEERING COLLEGE IN INDIA
}

\author{
Porag Kalita ${ }^{1}$ \\ ${ }^{1}$ Head: Automobile Engineering Department, Vocational Education (+2), M R S Higher Secondary School, Titabor, \\ Jorhat, Assam, India - 785630
}

\begin{abstract}
The concept of Quality Assurance in Engineering Institutions, used as long term policy. For the effectiveness, QA usually require a continuing evaluation factors towards design to providing confidence.

For the competitive environment, QA has gained wide importance in industry and is generally being introduced and experimental in educational institutions. However, educational system can't be treated as industry. But, there are similarities with respect to their sub-components. Each of these viewed, as a system consists of input, process, management, resource, output and feedback. Educational institution system is complex, as it involves human being as input and output from the system. Students are input and customer too.
\end{abstract}

Keywords: Quality Assurance, evaluation factors, process, resource $* * *$

\section{INTRODUCTION}

Quality policy shall be consistent with institutions policy and the top management must share all the necessary measures to ensure that its technical institution policy is clearly understood implemented and maintained. Quality policy shall cover the areas in terms of quality improvement and strategic planning:

1. The design,

2. Conformance of design, etc.

Education should not be given only for the sake of knowledge development. The knowledge and skills must be useful in our day-to-day life and it must be linked with our life practices. Therefore, education must make people undergo learning process throughout their life and gain the fullest potential for the individual's development. The concepts of lifelong education may be taught either direct or indirect or implicit way through various streams such as formal, informal and non-informal.

Here, teacher plays a pivotal roles such teaching demonstrating the life situation, conducting seminar and conference related lifelong education and other programme such as value enrichment programmes may be in social, religious, moral and ethical aspects, workshop on value practices, social linked programmes, creation programme to know the economic value of education and to know the problems that are present in the prevailing social condition and to solve the same.

\section{LITERATURE REVIEW:}

Mahatma Gandhi, father of Nation pointed out that the education system should also lay greater emphasis on work and practice while learning. He said that every citizen should be educated and the education must be job oriented for a better world and in this regard, Gandhian ideas focus on experiment.

Because, the last century the $20^{\text {th }}$ one was dominated by Europe, and the USA and to some extent by Japan. But, it is a fact that the present century will be dominated by AsiaPacific Region and very soon India will be ousted from the race. For example, in the year of 2000, it was estimated that $70 \%$ of the Hardware industries were under the control of China and $70 \%$ of the Software industries was under the Indian control. But astonishingly, the year of 2001-2002, picture was that China is going to chunk the major share of both Hardware and Software sectors.

Dr. Radhakrishnan rightly pointed out that education must develop humane, refine heart and sprit, import scientific habits of mind and promote learning to the present society and for the future society.

\section{METHODOLOGY}

\subsection{Implementation Process of Quality Policy}

There are five main steps used to implement the policy or quality programme towards Quality assurance in higher educational Institutions in North East India.

1. Understanding means :

(a) How does our quality system compare to the standards ISO 9000 series? In case, it matches then we are obtaining all the benefits of standards and the quality programme. The quality programme is to be implemented rather than impressing students. 
(b) Though, there is no national standard to advise regarding the best practice, but attempt to use statistics effectively.

(c) Asses the attitude and awareness of teachers about the quality programme.

\section{Top Management Commitment:}

(a) Top commitment means a positive direction of senior teacher to implement quality programme and there is no hidden intention to waste time and effort.

(b) To implement policy, try to explore the key areas - parents cum teachers, system and technology.

(c) It means educational/technical institutions wide awareness can be introduced top-to-bottom to implement policy, try to explore the key areaspeople, system and technology. Director /Principal may commit to introduce Total Quality circle (TQC) or Taguchi method but details should not be worked out at this stage.

(d) Good way to conveying the message ... What is quality and why is it important?

(e) What is the quality improvements programme and how each can participate?

\section{Planning}

(a) Planning means what you do, before you do anything plan it properly so that you do mix up the various activities when you do it,. This covers (i) Education, and (ii) Training.

\section{Implementation}

It means an accepted fact that the quality improvement programme is a continuous process and has got to be built into the system. Quantify the benefits.

\section{Review}

It means, to review the educational/technical institutions are emphasis on quality performances on regular basis. Review will improve the understanding to improve further. Etc.

From the above, Organization for Quality Management, towards development of effective system of quality assurance, depends on engineering college.. Structure of an organization is no guarantee to success, because it simply represents pictorial or graphical view of interlinking of various head of departments, who are responsible for quality.

As such the organization structure for quality management in engineering college may be different; however, the main objective is to implemented International Standard ISO 9000 series, so as to:

1. Clarify the distinctions and inter-relationship among the principal quality concepts, and

2. Provide guideline for the selection and use of a standard that can control the quality internally and externally to assure the quality.

\section{RESULT}

\subsection{Reliability and Maintainability}

The modern concept of Quality Assurance (QA) is normally used to achieve a balance of all the three aspects-1) Quality, 2) Reliability and 3) maintainability etc. As such the Total quality Control (TQC) has emerged out as an interdisciplinary engineering discipline, broadly encompassing ideas and methodologies:

1. Reliability engineering ensures that the concepts of design methodologies used to design the product or service would provide specified probability of trouble free operation for a desired period.

2. Classical inspection and quality control including statistical quality control (SQC) ensure acceptance or rejection.

3. Maintainability concepts and consideration ensure efficient diagnosis timely replacement or speedy from stage i.e. "on operation testing".

Reliability is showing a degree of dependability or level of confidence which is assumed to be stable. Dr. Taguchi has seven guides, which is gaining popularity in industry today. In this regard, a philosophy to contribute to the improvement and development of Reliability and Quality aspects in educational institutions are followed, but this philosophy will be better only when it is applied as a part of the TQM process.

1. Teachers develop their ability, wisdom and creation by using their brains.

2. Teachers do not work in isolation but act as a them,

3. Teachers educate themselves by sharing experienced,

4. It promote job involvement and participation,

5. Display human capabilities fully, etc.

The system of reliability model consists of some combination of a reliability block diagram or cause consequence chart. Thus a reliability block diagram is developed to calculate the system reliability. It is pictorial view system. Normally a system is constituted of a combination of-

1. Series combination,

2. Parallel combination and

3. Combination of the above two. Etc.

Series combination of any one would cause failure to the entire system then the parts are said to be in series from the functional point of view. So, if the failure of any constituent part results in system failure, then the reliability diagram is a contribution of elements, each with its own reliability function. The reliability of the system can be obtained from the multiplication of individual reliabilities.

$$
\begin{gathered}
\mathrm{Rs}(\mathrm{t})=\mathrm{R} 1(\mathrm{t}) . \mathrm{R} 2(\mathrm{t}) \ldots \mathrm{Rn}(\mathrm{t}), \quad(\text { When } \mathrm{Rs}(\mathrm{t})=\text { system } \\
\text { reliability) } \\
\mathrm{R} 1(\mathrm{t})=\mathrm{R} 2(\mathrm{t}) \ldots \mathrm{Rn}(\mathrm{t}) \ldots \text { The reliability of individual } \\
\text { element. }
\end{gathered}
$$




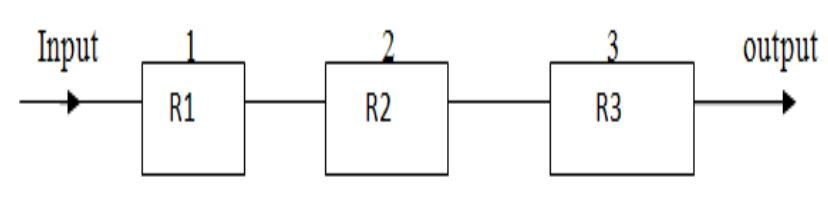

Fig 1: system in Series Combination

Therefore, reliability is to obtain trouble free performance for a specified operational period to Quality Assurance development.

\section{DISCUSSION}

Motivation programmes are the key for successful implementation of management policy and to achieve the objectives. These programmes ensuring the cooperation, assistance, and participation of teacher's effort to improve process and services. Therefore, quality planning or the quality shall ensure the participation of wide spectrum of teachers in the programmer's implementation. This will provide an opportunity of mass participation in management and to contribute in achieving or advancing the quality. Normally, the introduction of motivational programmes includes:

1. Zero-defect (ZD) programme,

2. Quality Control (QC) circles.

3. Incentives in the form of rewards. Etc

Motivational methods are not enough for successful QC circle programmes. Management's support, technical knowledge and statistical procedures are essential. Dr. Kaoru Ishikawa had said, 'A ten of enthusiasm is worthless backed by an ounce of scientific knowledge and attitude'.

\subsection{Type of Data}

The quality audit or survey is an appraisal of the quality system of an entire engineering college.. The quality survey is analogous to an accounting audit. The audit checks the details documents and accounting system. The complete quality survey or adult involves bringing together the data from the following investigation:

(a) To examine whether :

1. The quality towards design meets the functional requirements completely.

2. The design fulfils the student's requirements.

(b) To examine whether,

(c) To examine,

(d) To examine, various phases of quality performance. etc.

\section{CONCLUSION}

(1) Quality management is an aspect of overall management function that determines $\mathrm{s}$ and implements the quality and assures quality to students.

(2) Quality must become the first objective for all HOD/Teachers.

(3) Implementation of quality policy towards students delight.
(4) Manage to involve shop-floor staff in quality improvement programme.

(5) Educate, train and create awareness in all.

(6) Quality - Management shall not overlook the motivational programmes. Etc.

\section{ACKNOWLEDGEMENTS}

The author would like to thank the many people who helped and supported with this work. We received considerable tutorial information from UGC/NAAC/ICSSR sponsored National/International seminars /conferences and Course material from NCLM, Chennai with Management Development programme in XLRI and Executive Development programme in IIM Bangalore respectively.

\section{BIOGRAPHIES}

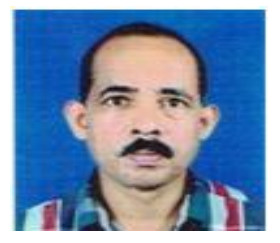

The author as Engineering Graduate, MBA along with Ph.D. in automobile engineering from International University, Washington, USA/2001 and Published numbers of research paper/projects completed i.e.

1. UGC sponsored national seminar: 85 Nos.

2. NAAC sponsored national seminar: 05 Nos.

3. CTE International Conference: 05 Nos

Guwahati University/Dibrugarh University/Assam University/: 32 Nos. Tezpur University/ Assam Agricultural university/UST, Shillong/ Institution

of Engineers, etc National/International seminar/ Conference.

4. SAE International Conference/Exposition i.e. USA/France: 07 Nos.

5. Recipient of BOLT Award/ Gold Medal etc: 05 Awards

6. Publication of Books : 07 Nos.

Now, doing in research on TQM \& ISO 9000, for the implementation in vocational education in $10+2$ level.

\section{REFERENCES}

[1]. Course Material, Executive Development Programme in IIM Bangalore, from July $17^{\text {th }}$ to $21^{\text {st }}, 1995$ and Course Director, Prof. L. Prasad.

[2]. Course Material, Management Development programme in XLRI, Jamshedpur, from January $2^{\text {nd }}$ to $6^{\text {th }}, 1995$ and Course Director Prof. M.V. Madan.

[3]. Proceeding of International Conference in $34^{\text {th }}$ Indian Social Science Congress at Guwahati University, from $27^{\text {th }}$ December to $31^{\text {st }} / 2010$.

[4]. Paper by Dr. Porag Kalita, CTE International Conference was held Guwahati University, Assam from $7^{\text {th }}$ November to $9^{\text {th }}, 2008$.

[5]. Proceeding of CTE International Seminar was held Dibrugarh University, Assam, from $7^{\text {th }}$ Feb to $9^{\text {th }} / 2013$.

[6]. Course Material (Private Circulation) from NCLM, Chennai, 1999.

[7]. Paper in UGC sponsored National Seminar with Assam College principal Council, at Pragjyotish College, Guwahati/2011. 
[8]. The Essence of TQM by John Bank.

[9]. Proceeding of National Seminar in Post Graduate Training College, North Lakhimpur, Assam, from $24^{\text {th }}$ November to $25^{\text {th }}, 2006$

[10]. Paper by Dr. Porag Kalita, NAAC sponsored National Seminar at J B Colleg, Jorhat, Assam from $4^{\text {th }}$ November to $5^{\text {th }}, 2006$

[11]. A Book, "Total Quality Management in Vocational Education (+2), by Dr. Porag Kalita.

[12]. Article in Assam Tribune on dated 17 December 2005.

[13]. An Introduction to ISO 9000 in M/S Good year India Ltd., New Delhi.

[14]. Proceeding of National Seminar in Post Graduate Training College, Jorhat, on date $20^{\text {th }}$ to 21 , Jan/2007. 